\title{
DIE GEHALTE EN GESTALTE VAN DIE PRAKTIESE TEOLOGIE SEDERT DIE BEGIN VAN DIE TWINTIGSTE EEU
}

\author{
deur \\ DR. J. I. DE WET
}

\section{Inleiding :}

Die Praktiese Teologie is van die vroegste tye af wetenskaplik beoefen. In die vierde eeu n.C. is daar alreeds op die gebied van die Praktiese Teologie, boake van min of meer wetenskaplike gehalte gepubliseer. Die volgende is sprekende bewyse : Peri Phugés ( \pm 365 n.C.) van Gregorius van Nazianze, Peri Hierosunés ( \pm 385 n.C.) van Chrysotomus; Liber Regulae Pastoralis ( \pm 591 n.C.) van Gregorius die Grote. Veral moet ook die De Doctrina Christiana en De Catechizandis Rudibus, oor prediking en kategese van Augustinus genoem word. Al kan hierdie geskrifte nie sondermeer as volwaardige Praktiese Teologieë bestempel word nie, lê hulle nietemin tog getuienis af van die min of meer wetenskaplike beoefening van die vak.

Nieteenstaande hierdie vroeë beoefening van die vak, moes die Praktiese Teologie tog nog baie lank wag om erkenning as teologiese vakwetenskap te verkry. Eers deur die werk van Schleiermacher, is sedert die begin van die 19de eeu, erken dat die Praktiese Teologie 'n ,positiewe” wetenskap met sy eie objek, metode en resultate is. Hiermee was alle struikelblokke egter nog nie uit die weg geruim nie. Daar het nog steeds allerlei vrae, wat op antwoorde gewag het, bestaan, soos bv. Wat is die werklike objek van die Praktiese Teologie? Watter nieteologiese hulpwetenskappe staan tot beskikking van die Praktiese Teologie? Watter gebruik mag die Praktiese Teologie van hierdie hulpwetenskappe se resultate maak? Wat is die verhouding tussen die Praktiese Teologie en die ander teologiese wetenskappe? Hierdie vrae kan nog grootliks vermeerder word. Dit is egter nis nodig nie. Hierdie gestelde vrae is in elk geval genoeg, sodat aan die hand van pogings tot beantwoording van hierdie vrae, die beoefening van die Praktiese Teologie van die afgelope halfeeu, ontleed, getipeer en beoordeel kan word.

Onses insiens kan daar veral drie hoofstrominge in die prakties-teologiese arbeid van die afgelope vyftig jaar opgemerk word. Dit moet egter dadelik gesê word, dat dit strominge is 
en nie skole nie. Hierdie drie strominge kan as volg getipeer word: (a) Die praktiese dinkrigting; (b) Die spekulatiewe dinkrigting en (c) Die prakties-teologiese dinkrigting.

Elkeen van hierdie strominge sal kortliks aan die hand van die vrae hierbo gestel bespreek word en die bespreking toegelig word met een geskrif wat verteenwoordigheid is van elke stroom en nie te lank gelede nie, gepubliseer is.

\section{A. Die Praktiese Dinkrigting :}

Dit was A. Kuyper wat in die vorige eeu grondliggende werk i.v.m. hierdie beskouing gedoen het. In sy Encyclopaedie deel III betoog hy dat die objek van die Praktiese Teologie die diakoniai as aanduiding van die dienste wat amptelik in die kerk verrig moet word, is. Hy verwerp die naam Praktiese Teologie en verkies die benaming Deaconiologiese Vakke as aanduiding van hierdie wetenskap.

By hierdie opvatting en die variante daarvan gaan dit in laaste instansie in die Praktiese Teologie om die vorm en metode van die kerklike verkondiging. Hoofsaak hierby is die vaardigheid waarmee die ampswerk verrig word. Ter illustrasie van hierdie feit kan verwys word na die versoek van 'n Hervormde Predikante-broederkring vanMiddelburg aan die Ned. Hervormde Kerk. $\left.{ }^{1}\right)$ Die Broederkring versoek nl. dat die ouer predikante die praktiese Praktiese Teologie aan die Kerk se opleiding te Pretoria moet behartig. Die bedoeling van die versoek is, dat die studente raad moet ontvang i.v.m. ,effektiewe" werkswyses wat deur die jare van ervaring in die ampsbediening ontwerp en toegepas is. Dat praktiese raadgewing uit die skat van die ervaring geput, baie waardevol kan wees, sal niemand betwyfel nie. Dog dit gaan in die Praktiese Teologie om veel meer as net die ampspraktyk en om veel meer as net 'n „effektiewe" ampspraktyk. Dit gaan bv. in die Praktiese Teologie, om maar net een saak te noem, ook om die vraag of die metode of werkswyse wat onmiddellike, sigbare resultate lewer, prinsipieël-teologies besien, noodwendig as ,effektief" vir die kerk gekwalifiseer moet word. By 'n noukeurige ontleding en teologiese evaluasie van die veronderstellings en agtergronde van sulke werkswyses, blyk dit heel dikwels dat sulke „effektiewe” metodes juis die teendeel bereik van wat as teologies verantwoord en gewens geag kan word.

1) Vgl. Agenda. Bevattende Beskrvwingspunte en Bylae tot die Agenda vir die vyf-en-vyftigste Algemene Kerkvergadering van die Ned. Hervormde Kerk van Afrika, bls. 65 en 66. 
II. Die vraag na die gebruik van die nie-teologiese hulp-

wetenskappe :

Uitgaande van die gedagte dat dit in die Praktiese Teologie om die ontwerp van ampstegnieke gaan, dus bloot om vorm en metode van die verkondiging, word die verhouding tussen die Praktiese Teologie en sy nie-teologiese hulpwetenskappe só bepaal dat dit eintlik daarop neerkom dat die Praktiese Teologie in hierdie hulpwetenskappe opgelos word. So word die homiletiek uitgelewer aan die retoriek asof 'n preek sondermeer dieselfde as 'n gewone toespraak is. Op dieselfde manier word ook die kategetiek en primeniek aan hulle hulpwetenskappe uitgelewer.

'n Sprekende voorbeeld van so 'n onderneming is bv. die Kleine Catechetiek ${ }^{2}$ ) van $\mathrm{R}$. Bijlema. Na 'n baie kort teologiesprinsipiëele uiteensetting wat geen verband hou met die verdere betoog nie, gaan Bijlsma rustig voort om sy kategetiek sondermeer in te rig volgens die gegewens van die metodiek van dagskoolonderwys.

Hierdie soort van beoefening van die Praktiese Teologie loop uiteindelik daarop uit dat die Praktiese Teologie 'n ontkerstende gehalte en gestalte vertoon. Dit lei onafwendbaar daartoe dat daar 'n eienaardige tweeslagtigheid in die kerk ontwikkel: Daar kom 'n gesekulariseerde praktyk in die kerk in aksie asof die kerklike praktyk los van en onaangeraak deur die teologiese principia ' $n$ eie bestaan kan voer. Al vertoon so'n praktyk dan ook hoe ,effektief”, kan dit kerklik net nie aanvaar word nie.

1II. Die Verhouding van die Praktiese Teologie tot die ander teologiese wetenskappe.

Dat hierdie hele dinkrigting die Praktiese Teologie bloot as 'n oop deur na die praktyk wat op enige ander gronde as teologiese gronde opgebou kan word, beskou, lê eintlik voor die hand. Dit is ook ewe duidelik dat die Praktiese Teologie volgens hierdie visie nie as 'n streng teologiese dissipline kan kwalfiseer nie. Daarom verbaas dit dan ook gladnie dat die Praktiese Teologie eers in 1911 in Duitsland erkenning as universitêre vak verkry het nie. Juis die feit dat die Praktiese Teologie as saak van kerklike tegnieke aangesien is, was ook daarvoor mede-verantwoordelik dat die Praktiese Teologie in Holland, saam met die Dogmatiek, aan die universiteite 'n plek ontsê is en onder die kategorie, kerklike vakke, tuisgebring is. Dit is

2) Gepubliseer in 1962 te G. F. Callenbach, Nijkerk. 
sekerlik ook in 'n nie te geringe mate te danke aan die invloed van die Hollandse gebruik dat Praktiese Teologie tot in 1961 as kerklike en nie as universitêre vak aan die Universiteit van Pretoria beoefen is.

\section{B. Die Spekulatiewe Dinkrigting}

Dat daar in teologiese kringe weerstand teen die praktiese rigting sou ontwikkel, is minstens te verwagte. Daarom staan daar ook teenoor die praktiese stroom, dié stroom wat as die spekulatiewe stroom getipeer kan word.

I. Die vraag na die objek van die Praktiese Teologie.

Vir hierdie stroom is slegs die aard en doel van die verkondiging, d.w.s. slegs die prinsipieële, die objek van die Praktiese Teologie. Waar die praktiese rigting die praktyk isoleer van die principia, daar isoleer hierdie spekulatiewe rigting weer die principia van die praktyk. Omdat die bootjie aan die een kant water geskep het, word daar só vér na die ander kant toe oorgeleun dat die water weer daar instroom. Klaarblyklik uit vrees dat die Praktiese Teologie weer kan verword tot 'n blote formulering van „effektiewe” tegnieke, laat die spekulatiewe rigting die besinning oor die formeel-metodiese aspekte van die verkondiging heeltemal links. Hierdeur word die Teologie behandel asof dit 'n organisme sonder lewensuiting kan wees. En langs hierdie weg word die Praktiese Teologie 'n teologie van lewens- en wêreldontvlugting.

Die geskrif Actuele Prediking ${ }^{3}$ ) van $H$. Jonker is 'n goeie illustrasie hiervan. Jonker gee in die boek 'n skitterende uiteensetting van die aard en doel van die prediking. Dan deins hy terug van die verantwoordelikheid om vanuit die prinsipiëelteologiese besinning riglyne vir die vorm en metode van die prediking te trek. Hy kom wel daartoe om wat hy 'n toeligting vanuit die praktyk noem, te gee. Daarmee slaag hy daarin om aan te toon dat sommige momente in die praktyk van die prediking miskien toevallig ooreenkoms met die teologiese principia vertoon. Hy bly egter heeltemal in gebreke om aan te toon dat die besondere praktyk beoefen word omdat dit op die besondere principia gebou is.

II. Die vraag na die verhouding tot die nie-teologiese hulpwetenskappe.

Juis omdat die gegewens van die nie-teologiese wetenskappe op die terrein van vorm en metode van die verkondiging hulle

3) Uitgegee in 1964 deur G. F. Callenbach, Nijkerk. 
rol speel en juis omdat die spekulatiewe rigting die vraag na vorm en metode as nie behorende tot die objek van die Praktiese Teologie beskou, is dit duidelik dat dit vir hierdie rigting eintlik nie ' $n$ vraag is of daar enige hulpwetenskappe tot beskikking van die Praktiese Teologie staan of nie. Dit is daarom ook nie 'n vraag op watter wyse die resultate van die hulpwetenskappe aangewend mag word nie. In hierdie opsig staan die spekulatieke rigting lynreg teenoor die praktiese. Die effek wat die spekulatiewe rigting het, is egter presies dieselfde as dié van die praktiese rigting, want dit lei ewe-eens tot die tweeslagtigheid in die kerk waar prinsipiële besinning en verkondigingspraktyk heeltemal los van mekaar bestaan.

\section{Die vraag na die verhouding met die ander teologiese wetenskappe.}

Die teologie is in geen deel studeerkamerspel of laboratoriumproef van die enkele geleerde nie. Teologie is die gelowige denke van die kerk oor die geloof en die lewe uit die geloof. Al word daar dan ook enkele geleerdes benoem om die teologie wetenskaplik te beoefen, dan is dit in elk geval nog só, dat hierdie geleerdes die teologie in die kerk en vir die kerk beoefen, sodat die kerk reg sal verkondig. Daarom kan die teologie goedskiks saam met van Oosterzee scientia ad praxin genoem word.

Omdat die Praktiese Teologie as scientia praxeos juis die teologiese vak is wat die taak het om die kerklike praktyk op die teologiese principia te fundeer en in ooreenstemming met die principia te bring, spreek dit vanself, dat, as die verkondigingspraktyk uitgesny word as nie behorende tot die objek van die Praktiese Teologie nie, die Praktiese Teologie eintlik nie meer bestaansreg as afsonderlike teologiese wetenskap het nie. Dan kan die werk wat die Praktiese nog doen, beskou word as onnodige duplikasie van die werk van die ander vakke en dan kan die Praktiese Teologie net so goed tuisgebring word onder die Dogmatiek en Christelike Etiek.

Met hierdie enkele opmerkings het dit duidelik geword dat daar ook teen die spekulatiewe rigting in die Praktiese Teologie baie besware ingebring kan word.

Behalwe hierdie praktiese en spekulatiewe stromings is egter ook nog 'n derde stroming in die beoefening van die Praktiese Teologie op te merk. Hierdie stroming wil ons tipeer met die benaming: Die prakties-teologiese dinkrigting. 


\section{Die Prakties-Teologiese Rigting :}

1. Die vraag na die objek van die Praktiese Teologie.

Hierdie dinkrigting kan nie beskou word as 'n sintese tussen die praktiese en spekulatiewe rigtings nie. Dit word duidelik by 'n nadere betragting van wat hierdie rigting as die objek van die Praktiese Teologie, beskou.

Otto Haendler kan beskou word as die beste verteenwoordiger van hierdie dinkrigting. In sy „Grundriss der Praktischen Theologie", ') betoog hy dat Praktiese Theologie, struktuurteologie van die hedendaagse kerk is. Wanneer hy van die kerk praat dan bedoel hy nie daarmee die kerk as voorwerp van ekklesiologiese besinning nie, maar wel die kerk as verkondigingsagens soos dit vandag in die wêreld essensieël eksisteer. Vir hom val essensie en eksistensie van die kerk as verkondigingsagens, saam. Dit gaan dus daarom dat die kerk slegs in die akte van die hoor en van die verkondiging van die gehoorde Woord, kerk is. Hierdie horende, verkondigende kerk is die studieobjek van die Praktiese Teologie. Die Praktiese Teologie moet die struktuur van hierdie horende, verkondigende kerk wetenskaplik ondersoek en beskrywe. Anders gesê : Praktiese Teologie is die wetenskaplike ondersoek en beskrywing van die aard, doel, vorm en metode van die verkondiging waardeur die kerk self in aansyn geroep word en waarmee die kerk self in die wêreld en aan die wêreld die Woord moet verkondig.

II. Die vraag na die verhouding tot die nie-teologieese hulpwetenskappe.

Die groot beswaar van Haendler teen die praktiese dinkrigting is dat dit in wese 'n vormwetenskap is wat die metodes van die nie-teologiese hulpwetenskappe sonder slag of stoot reglynig op kerklike objekte oordra. Andersyds hou hy dit teen die spekulatiewe rigting dat dit nie insien dat prinsipe en metode nie sondermeer geskei kan word nie, maar dat die prinsipe juis die metode medebepaal.

So kom hy tot die behartenswaardige uitspraak : „. . . dasz also z.B. Katechetik nicht nur auf Religion ongewendete Pādagogiek ist, sondern eine selbstāndige Parallelwissenschaft neben ihr, wobei vom Sachverhalt aus nicht nur die Katechetik von der Pādagogik zu lernen hat, sondern auch die Pādagogik von der Katechetik, oder nicht nur die Homiletik von der Rhetorik, sondern auch die Rhetorik von der Homiletik. (Das weltgeschict-

†) Uitgegee in 1957 by Alfred Töpelmann, Berlyn. 
liche eindruckvollste Beispel für diese das Wesen wandelnde Wirkung der Sachbeziehung auf die Methode ist der dem Christentum zu dankende Fortschritt von der griechischen Formalrethorik zur abendlāndischen Materialrethorik.). (bls. 6 \& 7).

Hy sien dus af van ontkerstening van die Praktiese Teologie deur die Praktiese Teologie terwille van sg. „effektiewe” tegnieke op te offer aan die nie-teologiese hulpwetenskappe. Hy sien ewe-eens af van ontkerstening van die Praktiese Teologie deur af te sien van 'n wêreldontwykende vlug in die spekulatiewe in. Hy kersten juis die Praktiese Teologie deur te bepaal dat die praktyk, dus vorm en metode, afgelei moet word van die principia en diensbaar moet wees aan die teologiese aard en doel van die kerklike verkondiging.

\section{Die verhouding tot die ander teologiese wetenskappe .}

Praktiese Teologie staan nie tussen wetenskap en praktyk nie. Dit is voluit wetenskap wat as die wetenskaplike beskrywing van die struktuur van die hedendaagse kerk deur die ander teologiese wetenskappe as scienntiae ad praxin nodig gemaak is en benodig word. D.w.s. Praktiese Teologie is as wetenskaplike beskrywing van die aard, die vorm en metode van die kerklike verkondiging verlengstuk van die ander teologiese wetenskappe en ook in ' $n$ heel bepaalde $\sin$ is dit die voorvereiste vir die ander teologiese vakke, omdat die Praktiese Teologie die wetenskap van die verkondiging is en die verkondiging die praktyk is waarheen die teologie beoefen word.

So sien Haendler die Praktiese Teologie as 'n integrale en onmisbare deel van die organiese geheel wat teologie genoem word. Die weglating van hierdie orgaan laat die organisme, die teologie as geheel, vermink agter.

\section{Slotopmerkings :}

As daar in die lig van die voorgaande parafraserende uiteensetting vir die toekoms 'n riglyn getrek moet word, dan verdien die volgende ernstige oorweging: Die Praktiese Teologie sal gekersten moet word. D.w.s. die Praktiese Teologie sal as struktuurteologie beoefen moet word. Sodoende sal daar ook in die beoefening van die teologie erns gemaak word met die egreformatoriese opvatting dat leer en lewe, principia en praxis, op mekaar moet pas, want ook in hierdie verband geld dit dat geloof wat nie gelewe word nie, dood is. 